\title{
DETERMINAN PERILAKU SEKSUAL BERISIKO PADA SISWA SMK
}

\author{
Dini Afriani' ${ }^{1}$, Siti Masyitah ${ }^{2}$, Santi Agustina ${ }^{3}$ \\ 1,2,3) Sekolah Tinggi Ilmu Kesehatan Sebelas April Sumedang \\ bydiniaf@gmail.com
}

\begin{abstract}
ABSTRAK
Remaja merupakan kelompok risiko perilaku seksual karena remaja merupakan suatu fase perkembangan antara masa kanak-kanak dan masa dewasa, berlangsung antara usia 12 sampai 21 tahun. Fase peralihan tersebut diikuti dengan pemikiran yang masih labil sering terbawa pergaulan tidak sehat dan terjerumus pada seks bebas (Perilaku seksual). Terdapat hubungan yang signifikan antara sikap dan perilaku seksual berisiko, tetapi penelitian sebelumnya belum melaporkan determinan perilaku berisiko pada siswa SMK Cihaurbeuti Ciamis, sebagian besar penelitian fokus kepada sikap remajanya. Jenis penelitian ini adalah kuantitatif non eksperirnental yaitu survei analitik yang dilakukan dengan cross sectional. Penelitian tersebut telah dilaksanakan pada bulan April 2019 di SMK Cihaurbeuti Ciamis. Penelitian ini menggunakan populasi total sebanyak 107 orang. Pengumpulan data menggunakan kuesioner determinan perilaku seksual berisiko. Data analisis yang digunakan yaitu analisis univariat yang dilakukan tehadap tiap variabel dari hasil penelitian dan menghasilkan distribusi dan persentase dari tiap variabel, analisis bivariat dilakukan terhadap dua variabel yang berhubungan atau berkorelasi menggunakan Uji Chi-Square, dan analisis multivariat menggunakan uji statistik regresi berganda. Hasil analisis multivariat dilihat dari Nilai Odd Ratio $(O R)$, semakin besar nilai OR semakin besar pengaruhnya pada variabel dependen. Hasil tiap variabel dengan OR 95\% CI yaitu pengetahuan 3,472, Media informasi 1,370, Teman sebaya 33,66, peran orang tua 2,833, Agama 0,683, status berpacaran 3,059, tempat tinggal 2, 746. Faktor yang paling dominan adalah teman sebaya dengan OR adalah 13,024 setelah dikontrol oleh variabel pengetahuan, peran orang tua, status berpacaran, dan tempat tinggal.
\end{abstract}

Kata kunci : perilaku seksual beresiko, pengetahuan tentang perilaku seksual, remaja

\section{Abstract}

Adolescents are a group of sexual behavior risk because adolescence is a phase of development between childhood and adulthood, lasting between the ages of 12 to 21 years, the transition phase is followed by a still unstable thinking that is likened to often getting carried away with unhealthy relationships and fall into free sex (Sexual behavior). There is a significant link between risky sexual attitudes and behaviors, but previous research has not reported determinants of risky behavior in vocational school students, most of which focus on adolescent attitudes. This type of research is quantitative non-experirnental which is an analytical survey conducted with cross sectional. The research was conducted in April 2019 at SMK Cihaurbeuti Ciamis. This study used a total population of 107 people. The data collection took place using a questionnaire determining risky sexual behavior. The analysis data used are univariate analysis conducted by each variable from the research results and produces the distribution and percentage of each variable, bivariate analysis is done on two variables related or correlated using chi-square test, and multivariate analysis using multiple regression statistical test, multivariate analysis result seen from odd ratio value, the greater odd ratio value the greater the effect on dependent variables. The result of each variable with OR 95\% CI is knowledge 3,472, Information media 1,370, Peers 33.66, parent roles 2,833, Religion 0.683, dating status 3,059, residence 2, 746. The most doininan factor is peers with Odds Ratio (OR) is 13,024 
after being controlled by variable Knowledge, Parent role, Dating status, Residence.

Keywords : adolescents, risky sexual behaviors, knowledge of sexual behavior

\section{PENDAHULUAN}

Pada penelitian sebelumnya di Amerika tahun 2017 berjudul Perilaku Seksual Remaja dan Reproduksi di Amerika Tengah: Tren Selama Dua Dekade Terakhir oleh Ghazaleh Samandari dan Ilene S. Speizer (Samandari \& Speizer, 2010) hasil penelitiannya tiga belas penelitian memenuhi kriteria inklusi yang berkaitan dengan remaja, fisiologi dan perilaku seksual kecuali studi yang berkaitan dengan perkembangan abnormal. Temuan menyoroti perbedaan hormonal dan gender. Pada penelitian tersebut wanita lebih dipengaruhi oleh aspek psikososial, termasuk pengaruh teman sebaya, dibandingkan pria. Pria mungkin lebih cenderung melakukan hubungan seks tanpa kondom dengan lebih banyak pasangan. Remaja yang dewasa awal lebih cenderung aktif secara seksual pada usia dini. Pada penelitian tersebut yang belum diteliti yaitu pengetahuan tentang perilaku seksual, media informasi, peran orang tua, religiositas (agama), status berpacaran, lokasi tempat tinggal.

Perilaku seksual yaitu sikap yang datang dari hasrat seksual baik yang dilakukan sendiri (masturbasi), lawan jenis ataupun sesama jenis tanpa adanya ikatan pernikahan dari agama. Objek seksualnya bisa berupa orang lain, orang dalam khayalan, atau diri sendiri.(Prawirohardjo, 2016)

Pada survei BKKBN gadis Ciamis melepas keperawananya di umur $15-22$ pada 5 tahun terakhir yaitu pada tahun 2014-2019. Hal tersebut terjadi dikarenakan banyak tempattempat yang mendukung bagi pelajar-pelajar SMA seperti yang marak dan ramai sekarang ini yaitu warnet, di dalam mobil, hotel, rumah yang kosong, dan bahkan sekolah pun bisa jadi sebagai salah satu tempat favorit pasangan gadis Ciamis. (BKKBN, 2020)

Hasil studi pendahuluan di SMK Cihaurbeuti Ciamis yang dilakukan dengan cara wawancarai siswi pada tanggal 24 Desember 2018, terkait 10 orang siswa 6 diantaranya menjawab dengan tegas pernah melakukan adegan ciuman bibir bersama pacarnya setelah pulang sekolah dilakukan di sekolah dan koskosan karena merasa nyaman di tempat yang terlihat sepi, 3 orang lainnya melihat teman sekelas mereka berciuman setelah itu meraba payudara, dan 1 orang siswa tidak pernah melakukan ataupun melihat perilaku seksual berisiko tersebut.

\section{METODOLOGI}

Jenis penelitian ini menggunakan metode pendekatan kuantitatif noneksperimental, dengan menggunakan Metode Survei Analitik dengan rancangan cross sectional. (Notoatmodjo, 2013) Pengumpulan data diperoleh dari penyebaran kuesioner kepada siswa dengan total sampel 107 siswa di SMK Cihaurbeuti Ciamis tahun 2019. Instrumen yang digunakan dalam penelitian ini adalah kuesioner. Kuesioner merupakan adaptasi dari penelitian orang lain yaitu Dewi Sri Susanti, yang berjudul Determinan perilaku seksual mahasiswa Akademi Kebidanan Borneo Medistra di Balikpapan tahun 2015. (Sasanti, 2019)

Kuesioner terdiri atas beberapa bagian, yaitu :

1. Perilaku seksual berisiko skala ordinal diisi oleh siswa, dinilai jika tidak berisiko apabila siswa memilih jawaban 1-3 diberi kode 0 , sedangkan apabila perilaku seksual berisiko siswa memilih jawaban 4-11 diberi kode 1 .

2. Pengetahuan seksual berisiko skala nominal 
diisi oleh siswa, dinilai baik jika menjawab benar $\geq 75 \%$ diberi kode 0 , sedangkan dinilai tidak baik Jika menjawab benar $<75 \%$ diberi kode 1.

3. Media informasi skala ordinal diisi oleh siswa, dinilai terpapar apabila skor jawaban responden $\geq$ median 4 diberi kode 0 , sedangkan apabila tidak terpapar skor jawaban responden $<$ median 4 diberi kode 1 .

4. Teman sebaya skala nominal diisi oleh siswa, dinilai tidak terpengaruh apabila nilai skor $\leq$ median 3 diberi kode 0 , sedangkan apabila terpengaruh jika nilai skor $>$ median 3 diberi kode 1.

5. Peran orang tua skala ordinal diisi oleh siswa, dinilai baik apabila skor jawaban responden $\geq$ median 5) diberi kode 0 , sedangkan apabila tidak baik skor jawaban responden $<$ median 5 diberi kode 1.

6. Religiositas (agama) skala nominal diisi oleh siswa, dinilai baik apabila skor jawaban responden $\geq$ median 2 diberi kode 0 , sedangkan apabila tidak baik jika skor jawaban responden $<$ median 2 diberi kode 1.

7. Status berpacaran skala ordinal diisi oleh siswa, dinilai apabila memilih tidak bepacaran diberi kode 0 , sedangkan apabila berpacaran diberi nilai 1.

8. Tempat tinggal skala ordinal diisi oleh siswa, dinilai apabila siswa tinggal bersama orang tua diberi kode nilai 0 , sedangkan apabila tidak tinggal bersama orangtua (kos, rumah saudara dll) diberi kode 1.

\section{Uji validitas dan Realibilitas}

Kuesioner diadaptasi dari penelitian orang lain yaitu Dewi Sri Susanti, yang berjudul Determinan Perilaku Seksual Mahasiswa Akademi Kebidanan Borneo Medistra di Balikpapan tahun 2015 (Sasanti, 2019). Kuesiner tersebut belum dapat digunakan peneliti sebagai alat ukur karena ada 1 pertanyaan yang diganti pada variabel pengetahuan sehingga harus dilakukan uji validitas dan reliabilitasnya. Uji coba dilakukan di Madrasah Aliyah Ciamis dengan responden 15 siswa.

Hasil nilai uji statistik sebagai berikut :

1) Variabel pengetahuan perilaku seksual Hasil uji validitas pada 10 pertanyaan tersebut dinyatakan valid karena setiap butir pertanyaan mendapat $r$ hasil $>0,514$.

Adapun hasil uji reliabilitas variabel pengetahuan perilaku seksual nilai Cronbach's alpha sebesar 0,971 .

\section{Analisis Data}

1. Analisis Univariat

Analisis univariat dilakukan pada tiap variabel hasil penelitian. Analisis tersebut menghasilkan distribusi frekuensi, persentase dari setiap variabel.(Arikunto, 2006).

2. Analisis Bivariat

Analisis bivariat yaitu untuk mencari hubungan terhadap dua variabel. Metode yang dipakai untuk melihat hubungan kedua variabel tersebut memakai Uji Statistik ChiSquare.

3. Analisis Multivariat

Analisis multivariat menggunakan Uji Statistik Regresi Berganda.

\section{HASIL}

\section{Hasil Analisis Univariat}

Tabel 1. Distribusi Frekuensi Determinan

Perilaku Seksual Berisiko pada Siswa di SMK Cihaurbeuti Ciamis

\begin{tabular}{lcc}
\hline Variabel & f & $\mathbf{\%}$ \\
\hline $\begin{array}{l}\text { Perilaku Seksual } \\
\text { Berisiko }\end{array}$ & & \\
Tidak risiko & 86 & 80,4 \\
Risiko & 21 & 19,6 \\
\hline Total & 107 & 100 \\
\hline Pengetahuan & & \\
Baik & 56 & 52,3 \\
\hline
\end{tabular}




\begin{tabular}{lcc}
\hline Variabel & $\mathbf{f}$ & $\mathbf{\%}$ \\
\hline Tidak baik & 51 & 47,7 \\
\hline Total & 107 & 100 \\
\hline Teman Sebaya & & \\
Tidak terpengaruh & 66 & 61,7 \\
Terpengaruh & 41 & 38,3 \\
\hline Total & 107 & 100 \\
\hline Media Informasi & & \\
Tidak terpapar & 77 & 72,0 \\
Terpapar & 30 & 28,0 \\
\hline Total & 107 & 100 \\
\hline Peran Orang Tua & & \\
Baik & 63 & 58,9 \\
Tidak baik & 44 & 41,1 \\
\hline
\end{tabular}

\begin{tabular}{lcc}
\hline Variabel & f & $\mathbf{\%}$ \\
\hline Total & 107 & 100 \\
\hline Agama & & \\
Baik & 75 & 70,1 \\
Tidak baik & 32 & 29,9 \\
\hline Total & 107 & 100 \\
\hline Status Berpacaran & & \\
Tidak pacaran & 59 & 55,1 \\
Berpacaran & 48 & 44,9 \\
\hline Total & 107 & 100 \\
\hline Tempat Tinggal & & \\
Rumah orang tua & 30 & 28,0 \\
Kos/ rumah saudara & 77 & 72,0 \\
\hline Total & 107 & 100 \\
\hline
\end{tabular}

Hasil Analisis Bivariat

Tabel 2. Rekapitulasi Analisis Bivariat Determinan Perilaku Seksual Berisiko pada Siswa di SMK Cihaurbeuti Ciamis

\begin{tabular}{|c|c|c|c|c|c|c|c|}
\hline \multirow{3}{*}{ Variabel } & \multicolumn{4}{|c|}{ Perilaku Seksual Berisiko } & \multirow{3}{*}{ Total } & \multirow{3}{*}{ p-value } & \multirow{3}{*}{ OR $(95 \% C I)$} \\
\hline & \multicolumn{2}{|c|}{ Tidak Berisiko } & \multicolumn{2}{|c|}{ Berisiko } & & & \\
\hline & $\mathbf{n}$ & $\%$ & $\mathbf{n}$ & $\%$ & & & \\
\hline \multicolumn{8}{|l|}{ Pengetahuan } \\
\hline Baik & 50 & 89,3 & 6 & 10,9 & 100 & \multirow{2}{*}{0,029} & 3,472 \\
\hline Tidak baik & 36 & 70,6 & 15 & 29,4 & 100 & & $(1,228-9,816)$ \\
\hline \multicolumn{8}{|l|}{ Teman Sebaya } \\
\hline Tidak terpapar & 58 & 87,9 & 8 & 12,1 & 100 & \multirow{2}{*}{0,026} & 3,366 \\
\hline Terpapar & 28 & 68,3 & 13 & 31,7 & 100 & & $(1,251-9,054)$ \\
\hline \multicolumn{8}{|l|}{ Media Informasi } \\
\hline Tidak terpapar & 63 & 81,8 & 14 & 18,2 & 100 & \multirow{2}{*}{0,740} & 1,370 \\
\hline Terpapar & 23 & 76,7 & 7 & 23,3 & 100 & & $(0,493-3,818)$ \\
\hline \multicolumn{8}{|l|}{ Peran Orang Tua } \\
\hline Baik & 55 & 87,3 & 8 & 12,7 & 100 & \multirow{2}{*}{0,056} & 2,883 \\
\hline Tidak baik & 31 & 70,5 & 13 & 29,5 & 100 & & $(1,077-7,717)$ \\
\hline \multicolumn{8}{|l|}{ Agama } \\
\hline Baik & 59 & 78,7 & 16 & 21,3 & 100 & \multirow{2}{*}{0,678} & 0,683 \\
\hline Tidak baik & 27 & 84,4 & 5 & 15,6 & 100 & & $(0,277-2,057)$ \\
\hline \multicolumn{8}{|l|}{ Status Berpacaran } \\
\hline Tidak pacaran & 52 & 88,1 & 7 & 11,9 & 100 & \multirow{2}{*}{0,046} & 3,059 \\
\hline Berpacaran & & & & & & & $(1,120-8,356)$ \\
\hline \multicolumn{8}{|l|}{ Tempat Tinggal } \\
\hline Rumah orang tua & 27 & 90,0 & 3 & 10,0 & 100 & \multirow{2}{*}{0,196} & 3,059 \\
\hline Kos/ rumah saudara & 59 & 76,6 & 18 & 23,4 & 100 & & $(0,745-10,119)$ \\
\hline
\end{tabular}


Tabel 3. Hasil Analisis Multivariat

\begin{tabular}{lccc}
\hline Variabel & B & p-value & OR \\
\hline Teman sebaya & 2,567 & .001 & 13.024 \\
Status pacaran & 2,059 & .012 & 7.834 \\
Pengetahuan & -895 & .206 & 2.447 \\
Tempat tinggal & 1.073 & .154 & 2.923 \\
\hline
\end{tabular}

Tabel 4. Pemodelan Multivariat Akhir

\begin{tabular}{|c|c|c|c|c|c|c|c|}
\hline \multirow{3}{*}{ Variabel } & \multicolumn{4}{|c|}{ Perilaku Seksual Berisiko } & \multirow{3}{*}{ Total } & \multirow{3}{*}{ p-value } & \multirow{3}{*}{ OR(95\%CI) } \\
\hline & \multicolumn{2}{|c|}{ Tidak Berisiko } & \multicolumn{2}{|c|}{ Berisiko } & & & \\
\hline & $\mathbf{n}$ & $\%$ & $\mathbf{n}$ & $\%$ & & & \\
\hline \multicolumn{8}{|l|}{ Tempat Tinggal } \\
\hline Rumah orang tua & 27 & 90,0 & 3 & 10,0 & 100 & \multirow{2}{*}{0,196} & 2,746 \\
\hline Kos/ rumah saudara & 59 & 76,6 & 18 & 23,4 & 100 & & $(0,745-10,119)$ \\
\hline Total & 86 & 80,4 & 21 & 19,6 & 100 & & \\
\hline
\end{tabular}

Hasil analisis multivariat dihasilkan bahwa pengaruh teman sebaya dan status pacaran berhubungan dengan perilaku seksual berisiko pada siswa. Adapun tempat tinggal dan pengetahuan merupakan variabel confounding. Hasil analisis didapatkan Odds Ratio (OR) dari variabel pengaruh teman sebaya adalah 13,024 artinya siswa yang terpengaruh teman sebaya mempunyai risiko untuk berperilaku seksual 13,0 kali lebih besar dibandingkan siswa yang tidak terpengaruh teman sebaya. Jadi variabel yang dominan berhubungan dengan perilaku seksual berisiko pada siswa adalah pengaruh teman sebaya.

\section{PEMBAHASAN}

Gambaran Perilaku Seksual Berisiko pada Siswa SMK Cihaurbeuti Ciamis

Pada penelitian ini mendapat hasil yang sama dengan penelitian Mahmudah di Sumatra Barat (Padang) tahun 2016 (Mahmudah et al., 2016) adalah perilaku seksual di Kota Padang dengan hasil berperilaku seksual $(20,9 \%)$ dan tidak berisiko $(79,1 \%)$. Penelitian tersebut analitik, jumlah sampelnya adalah 158 orang.

Menurut peneliti gambaran perilaku seksual berisiko di SMK Cihaurbeuti Ciamis cukup banyak yaitu 21 siswa dari 107 responden. Hal tersebut disebabkan oleh kurang paham akan pengetahuan seksual berisiko yaitu pengetahuan tentangkesehatanalat reproduksi, seperti: anatomi sistem reproduksi, beserta fungsi reproduksi, dan cara-cara pencegahan serta penanggulangan terhadap kehamilan, persalinan, aborsi, penyakitpenyakit kelamin lainnya. Selain itu, remaja yang kurang pengetahuan mengenai perilaku seksual berisiko. Para remaja beranggapan yang kurang tepat tentang hubungan seksual berisiko diantaranya kehamilan tidak mungkin terjadi bila hubungan seksual hanya dilakukan satu kali saja.

\section{Hubungan Antara Pengetahuan Siswa dengan Perilaku Seksual Berisiko pada Siswa SMK Cihaurbeuti Ciamis}

Penelitian tersebut mendapat hasil yang sama dengan penelitian Harni Andriani, Yasnani, Arum yang di Kendari Tahun 2016 mengenai hubungan pengetahuan dengan 
perilaku seksual berisiko(Andriani et al., 2016) Hasil penelitian Uji Statistik Chi-Square pada tingkat kepercayaan $95 \%(\alpha=0,05)$ menunjukan bahwa $\rho$-value $=0,030$, jadi $\rho$-value $<\alpha(0,05)$ sehingga Ho ditolak dan Ha diterima, artinya ada hubungan antara pengetahuan dengan perilaku seksual remaja di SMK Negeri 1 Kendari.

Menurut peneliti pengetahuan adalah hasil dari tahu atau mengetahui dan ini terjadi setelah seseorang melakukan pengamatan pada suatu objek tertentu. Pengetahuan tersebut untuk menghasilkan suatu perilaku atau sikap tertentu ketika menghadapi suatu keadaan. Pengetahuan disini yaitu diantaranya mengenai perilaku seksual berisiko, bagaimana bisa hamil dan lainlain.

\section{Hubungan Antara Media Informasi dengan Perilaku Seksual Berisiko pada Siswa SMK Cihaurbeuti Ciamis}

Penelitian tersebut berbeda dengan hasil penelitian Harni Andriani, Yasnani, Arum yang di Kendari Tahun 2016 (Andriani et al., 2016) mengenai hubungan media informasi dengan perilaku seksual berisiko. Hasil analisis Uji Statistik Fisher's Exact Test diperoleh nilai P atau nilai signifikansi adalah 0,010 dan $\alpha$ yaitu 0,05 . Nilai P lebih kecil dari $\alpha$, maka hasil hipotesis Ho ditolak dan Ha diterima artinya ada hubungan antara akses media informasi dengan perilaku seksual. Dengan demikian dapat disimpulkan yaitu akses media informasi mempunyai hubungan yang sedang dengan perilaku seksual siswa SMK Negeri 1 Kendari Kota Kendari Tahun 2016.(Andriani et al., 2016)

Menurut peneliti hasil penelitian ini tidak ada hubungan antara media informasi dengan perilaku seksual berisiko terhadap siswa dikarenakan rasa ingin tahu pada remaja tentang suatu hal sangat tinggi, sumber informasi yang mudah mereka jangkau adalah teman teman dan media (VCD porno, akses internet). Hampir setiap remaja memiliki handphone, laptop, dan media elektronik lainnya sehingga sangat mudah dalam mengakses video yang tidak sesuai dengan usianya sehingga semakin siswa banyak mengakses tentang pornografi pada media eletronik, cetak dll semakin tahu mengenai seksual berisiko dan berkeinginan melakukan perilaku seksual berisiko atau menyalurkan hasrat seksualnya. Namun, kembali lagi penelitian ini dilakukan di sekolah terpencil di kabupaten, bahwa tidak semua media informasi mereka miliki seperti handphone, laptop dan akses internet yang bagus sulit didapatkan terlebih jadwal sekolah dari pagi hingga sore sehingga sedikit waktu untuk mengakses media informasi.

\section{Hubungan Antara Teman Sebaya dengan Perilaku Seksual Berisiko terhadap Siswa SMK Cihaurbeuti Ciamis}

Penelitian ini mendapat hasil yang sama dengan penelitian Nia Yulianti tahun 2015 di Yogyakarta mengenai pergaulan teman sebaya dengan perilaku seksual terhadap remaja. (Gelar et al., 2014) Hasil Uji Fisher's Exact menampilkan adanya hubungan antara pergaulan teman sebaya dengan perilaku seks terhadap siswa kelas XI IPS di SMA Negeri 1 Semin Gunung Kidul Yogyakarta $(<0,05)$.

Menurut peneliti bahwa ada hubungan teman sebaya dengan perilaku seksual berisiko pada siswa dikarenakan teman sebaya atau sahabat terdekat satu lingkungan sebaya adalah teman yang berada pada umur yang sama dan diantara mereka biasanya terjalin keakraban dan saling bercerita satu sama lainnya apabila ada masalah. Begitupun peranan dari teman sebaya pada perkembangan remaja sangat besar dalam kehidupan remaja sehari-hari termasuk gaya berpacaran menjadi model atau acuan yang digunakan seseorang remaja dalam pacaran 
karena berada dalam lingkungan yang sama.

\section{Hubungan Antara Peranan Orang Tua dengan Perilaku Seksual Berisiko Berisiko pada Siswa SMK Cihaurbeuti Ciamis}

Penelitian ini mendapat hasil yang berbeda dengan penelitian Harni Andriani, Yasnani, Arum yang di Kendari Tahun 2016 (Andriani et al., 2016) mengenai hubungan peran orang tua dengan perilaku seksual pada remaja. Hasil analisis Uji Statistik Continuity Correction diperoleh nilai $\mathrm{P}$ atau nilai signifikansi adalah 0,040 dan $\alpha$ adalah 0,05 , nilai P lebih kecil dari $\alpha$, maka hipotesis Ho ditolak dan Ha diterima yaitu ada hubungan antara peranan keluarga atau orang tua dterhadap perilaku seks pada remaja. Adapun analisis uji keeratan hubungan diperoleh nilai Phi $(\varnothing)=0,328$. Angka tersebut menunjukkan hubungan yang sedang karena terletak antara 0,26-0,50. Dengan demikian dapat disimpulkan bahwa variabel peran keluarga atau orang tua memiliki hubungan yang sedang dengan perilaku seksual siswa SMK Negeri 1 Kendari Kota Kendari Tahun 2016.(Andriani et al., 2016)

Menurut peneliti pada penelitian ini yaitu tidak ada hubungan peranan orang tua dengan perilaku seksual berisiko terhadap siswa dikarenakan tidak semua siswa di tempat penelitian $100 \%$ diawasi orang tua, karena ada yang tinggal di kos dll tetapi peranan aktif orang tua yaitu ibu/bapak/wali dalam berkomunikasi dengan anaknya memiliki peranan yang penting dalam membentuk karakter, mindset anak dan perilaku anak. Selain itu, berbicara dan saling berhubungan melalui komunikasi yang tepat akan memberikan gambaran atau pandangan mengenai pemaknaan seks dan pendidikan seks yang benar sehingga anak mengerti batasan yang baik dan tidak baik untuk mereka. Peranan orang tua berfungsi sebagai pendidik pertama dan utama bagi anaknya dalam rumah. Peranan orang tua terhadap anaknya merupakan awal benih akal penyusunan kematangan individu dan struktur kepribadian yang baik. Anak-anak menilai dan mengikuti orang tua dan berbagai kebiasaan dan perilaku, anak sangat membutuhkan orangt tua, keluarga dan rasa aman nyaman yang diperoleh dari ibu dan rasa terlindung dari ayah.

\section{Hubungan Reliugitas (Agama) dengan Perilaku Seksual Berisiko terhadap Siswa SMK Cihaurbeuti Ciamis}

Penelitian tersebut mendapat hasil yang sama dengan penelitian Puspita di Surakarta mengenai hubungan agama dengan perilaku seksual berisiko. (Puspita et al., 2020). Pada analisis data yang dilakukan dengan memakai Teknik Analisis Korelasi Product Moment dari Pearson yang dibantu program SPSS 15 For Windows dapat diketahui nilai koefisien korelasi $\mathrm{r}$ sebesar - 0,217 dan sig $=0,065: \mathrm{p}>0,05$, sehingga menunjukan bahwa tidak ada hubungan yang signifikan antara agama dengan perilaku seks bebas, sehingga disimpulkan yaitu perilaku seks bebas tidak dipengaruhi oleh religiositas atau agama.

Menurut peneliti ini tidak ada hubungan antara agama dengan perilaku seksual berisiko terhadap siswa dikarenakan tingkat pengetahuan agama, kokoh keyakinan terhadap Tuhan, giat seseorang itu dalam melaksanakan ibadah dan kaidah agama yang dianutnya, dan seberapa dalam seseorang menghayati agamanya tidak memengaruhi seseorang untuk mengambil keputusan terutama dalam melakukan hubungan seksual berisiko, terlebih responden penelitian masih remaja, dikelilingi teman sebaya yang terbiasa melakukan hubungan seksual berisiko, peran orang tua yang kurang emngawasi anak anaknya, serta tempat tinggal yang bebas sehingga membuat remaja yang belum punya pedoman hidup tinggi atau masih labil sehingga mudah saja untuk terjerumus dalam melakukan 
hubungan seksual berisiko.

\section{Hubungan Antara Status Pacaran dengan Perilaku Seksual Berisiko terhadap Siswa SMK Cihaurbeuti Ciamis}

Penelitian tersebut mendapatkan hasil sama dengan penelitian Christine Ohee di Surabaya mengenai status pacaran dengan perilaku seksual berisiko.(Ohee, 2019) Dari hasil penelitian diperoleh proporsi oleh responden yang melakukan pacaran berisiko dengan status sedang pacaran $(93,5)$, yang tidak pacaran dan melakukan pacaran berisiko $(30,8 \%)$, dan yang melakukan pacaran berisiko dengan pacaran jarak jauh $(36,4 \%)$ berarti mahasiswa perantau asal Papua yang sedang berpacaran lebih banyak melakukan pacaran berisiko yang mengarah ke perilaku seks.

Menurut peneliti ada hubungan antara status berpacaran perilaku seksual berisiko terhadap siswa dikarenakan status berpacaran merupakan gerbang menuju melakukan hubungan seksual. Siswa atau remaja lebih memilih untuk berpacaran di sekolah sebagai penyemangat untuk belajar dll, berpacaran membuat seseorang tersebut memiliki hasrat seksual antara kedua lawan jenis akan memengaruhi terjadinya hubungan seksual, karena hasrat hubungan seksual timbul kapan saja dan dimana saja, tergantung bagaimana bisa mengontrol diri, dengan demikian pula dengan siswa perilaku seksual berisiko pada siswa dapat dipengaruhi oleh kebebasan saat berada di sekolah tanpa ada ikatan status berpacaran,

\section{Hubungan Antara Lokasi Tempat Tinggal} Siswa dengan Perilaku Seksual terhadap Siswa SMK Cihaurbeuti Ciamis

Penelitian tersebut berbeda dengan Erna mesra tahun 2016 mengenai tempat tinggal dengan perilaku seksual berisiko di Jakarta .(Mesra, 2016). Hasil penelitian lokasi tempat tinggal siswa berhubungan signifikan dengan perilaku seks. Lokasi tempat tinggal yang tidak kondusif memiliki perilaku seks berat sebanyak $73.9 \%$ sedangkan lingkungan tempat tinggal yang kondusif memiliki perilaku seks berat sebanyak $43.9 \%$.

Menurut peneliti tidak ada hubungan antara lokasi tempat tinggal dengan perilaku seks pada siswa di SMK Cihaurbeuti Ciamis dikarenakan pada kosan/ rumah pasti selalu ada penghuni yang lain sehingga sulit untuk melakukan perilaku seksual beresiko. Apabila kosan sepi atau tidak ada yang mengawasi remaja cenderung was-was untuk melakukan hubungan seksual.

\section{Analisis Multivariat}

Hasil penelitian ini menunjukkan variabel paling dominan adalah teman sebaya. Teman dekat atau teman sebaya yaitu teman yang selalu ada di dekat dalam satu lingkungan baik di sekolah maupun diluar sekolah. Teman sebaya yang berada pada lingkaran umur yang sama dan diantara mereka pada siswa-siswi biasanya terjalin keakraban yang cukup dekat. Peranan teman dekat atau sahabat sebaya terhadap siswa atau remaja cukup besar dalam kehidupan siswa sehari-hari. Model berpacaran teman dekat atau sahabat sebaya menjadi model atau gaya, dan acuan yang dilakukan seorang siswa ketika berpacaran. Adanya dukungan teman sebaya menjadi suatu jalinan ikatan yang cukup kuat. Pada siswa- siswi lebih banyak berada di luar rumah atau di sekolah bersama teman sebaya atau sahabat dekat sebagai suatu lingkaran kelompok, adanya dukungan pengaruh teman-teman sebaya atau sahabat dekat pada saat melakukan sikap, pembicaraan seperti curhat, tentang minat, dan perilaku terkait lebih besar dari pengaruh keluarga. 


\section{SIMPULAN DAN SARAN}

\section{Simpulan}

Berdasarkan hasil analisis determinan perilaku seksual berisiko pada siswa di SMK Cihaurbeuti Ciamis dapat disimpulkan sebagai berikut :

1. Siswa di SMK Cihaurbeuti Ciamis tahun 2019 mendapatkan bahwa sebesar 86 siswa $(80,4 \%)$ memiliki perilaku seksual tidak berisiko dan sebanyak 21 siswa $(19,6 \%)$ memiliki perilaku seksual berisiko.

2. Variabel yang mempunyai hubungan dengan perilaku seksual berisiko dari variabel independen yaitu pengetahuan, teman sebaya, status berpacaran.

3. Faktoryangpalingdominanyangberhubungan dengan perilaku seks pada siswa di SMK Cihaurbeuti Ciamis tahun 2019 adalah teman sebaya dengan OR sebesar 13,024 setelah dikontrol oleh variable pengetahuan, peran orang tua, status berpacaran, tempat tinggal.

4. Variabel yang tidak berhubungan dengan perilaku seksual berisiko yaitu variabel religiositas (agama), media informasi, peran orang tua, tempat tinggal.

\section{Saran}

\section{Bagi SMK}

Hasil penelitian tersebut diharapkan dapat memberikan pengetahuan dan solusi bagi pihak sekolah/SMK terkait kesehatan reproduksi khususnya perilaku seks berisiko sehingga bisa mengurangi dan menanggulangi perilaku seksual berisiko terhadap siswa siswi di SMK Cihaurbeuti Ciamis.

2. Bagi Masyarakat

Hasil Penelitian ini hendaknya informasi dan edukasi mengenai pentingnya pendidikan perilaku seksual pada remaja dan mengenai kesehatan reproduksi selain itu masyarakat menjadi lebih memantau aktivitas siswa-siswi yang berada di sekitar lingkungan masyrakat terutama kosan, sehingga mengurangi perilku seks berisiko.

3. Bagi Puskesmas

Hasil Penelitian ini hendaknya menjadi bahan informasi dan masukan Puskesmas untuk mengembangkan Pelayanan Kesehatan Ramah Remaja (PKPR) dengan cara datang ke sekolah memberikan penyuluhan mengenai kesehatan reproduksi.

4. Bagi Institusi Kesehatan Masyarakat Hasil penelitian ini diharapkan dapat berguna sebagai catatan atau list yang harus segera di atasi sehingga bisa melalukan penelitian lebih lanjut pada siswa siswi di sekitar lingkungan tersebut agar segera atas terkait kesehatan reproduksi khususnya perilaku seks bebas di kota tersebut.

5. Bagi Peneliti Selanjutnya

Diharapkan hasil peneliti ini dapat digunakan sebagai media pembelajaran dan menambah referensi bagi peneliti. Selanjutnya untuk lebih memperdalam ilmu perilaku seksual beresiko dan Mengetahui lebih jelas mengenai variabel yang diteliti dan diharapkan bagi peneliti selanjutnya untuk meneliti variabel yang belum diteliti.

\section{DAFTAR PUSTAKA}

Andriani, H., Yasnani, Y., \& Pratiwi, A. (2016). Hubungan Pengetahuan, Akses Media Informasi Dan Peran Keluarga Terhadap Perilaku Seksual Pada Siswa Smk Negeri 1 Kendari Tahun 2016. Jurnal Ilmiah Mahasiswa Kesehatan Masyarakat Unsyiah.

Arikunto, S. (2006). Prosedur Penelitian Suatu Tindakan Praktik. Jakarta: Rineka Cipta. BKKBN. (2020). Gambaran Umum Kampung KB. In Kampung KB.

Gelar, M., Keperawatan, S., Program, P., Studi, P. N., \& Keperawatan, I. (2014). Program Studi Ilmu Keperawatan Sekolah Tinggi 
Ilmu Kesehatan 'Aisyiyah.

Mahmudah, M., Yaunin, Y., \& Lestari, Y. (2016). Faktor-Faktor yang Berhubungan dengan Perilaku Seksual Remaja di Kota Padang. Jurnal Kesehatan Andalas, 5(2), 448-455. https://doi.org/10.25077/jka. v5i2.538

Mesra, E. (2016). Pengaruh Teman Sebaya Terhadap Perilaku Seksual Remaja. Jurnal Ilmiah Bidan, 1(2), 34-41.

Notoatmodjo, S. 2010. M. P. K. J. : R. C. (2013). Notoatmodjo, S. 2010. Metodologi Penelitian Kesehatan. Jakarta: Rineka Cipta. In Journal of Chemical Information and Modeling.

Ohee, C. (2019). Pengaruh Status Hubungan Berpacaran Terhadap Perilaku Pacaran Berisiko Pada Mahasiswa Perantau Asal Papua Di Kota Surabaya. The Indonesian Journal of Public Health, 13(2), 269. https://doi.org/10.20473/ijph. v13i2.2018.269-287

Prawirohardjo, S. (2016). Ilmu Kebidanan
Sarwono Prawirohardjo. Edisi Ke-4. Jakarta: Yayasan Bina Pustaka Sarwono Prawirohardjo.

Puspita, I. A., Agusybana, F., \& Dharminto, D. (2020). Hubungan Penggunaan Media Sosial dan Peran Teman Sebaya dengan Perilaku Seksual Berisiko di SMK Kota Surakarta. Jurnal Kesehatan. https://doi. org/10.25047/j-kes.v7i3.113

Samandari, G., \& Speizer, I. S. (2010). Adolescent sexual behavior and reproductive outcomes in Central America: Trends over the past two decades. International Family Planning Perspectives. https:// doi.org/10.1363/3602610

Sasanti, D. A. (2019). Determinan Perilaku Seksual Mahasiswa Akademi Kebidanan Borneo Medistra di Balikpapan Tahun 2015. Bunda Edu-Midwiifery Journal (BEMJ), 2(1), 40-48. https://www.neliti. com/publications/277231/determinanperilaku-seksual-mahasiswa-akademikebidanan-borneo-medistra-di-balik 